\title{
Effects of Metformin used in Surgical Treatment of Intrabony Periodontal Defect: A Comparative Clinical and Radiographic Study
}

\author{
Hossam G. Mahmoud" ${ }^{* 1}$, Asem M. Kamel ${ }^{1}$, Fathy Abdel A. Abo Zaid ${ }^{1}$
}

Codex : 12/2021/04

Aadj@azhar.edu.eg

\section{KEYWORDS}

Keywords: metformin,

Periodontitis, Intrabony defects,

Regeneration, periodontal pocket

1. Department of Oral Medicine, Periodontology, Oral Diagnosis and Dental Radiology, Faculty of dental medicine, (Assiut, boys), Al-Azhar University, Egypt.

* Corresponding Author e-mail: hossamabdelwahab.2046@azhar.edu.eg

\begin{abstract}
Aim: this study preformed to evaluate clinically and radiographically, the efficacy of Metformin Gel in the surgical treatment of intrabony periodontal defects. Subjects and methods: Twenty chronic periodontitis patients with intrabony defect were divided randomly into two groups. Group I: ten patients with infrabony defects treated by open flap surgery only. Group II: ten patients with infrabony defects treated by open flap surgery combined with metformin gel $1 \%$. Clinical and radiographic parameters were gathered at baseline, 6 and 9 months. Results: There were statistically significant differences between Group I \& Group II at 6 months regarding probing depth, clinical attachment level and marginal bone level. And vice versa, no statistically significant differences at 9 months. Conclusions: usage of metformin gel 1\% seems to be superior in gaining bone than surgical treatment by open flap surgery only but this improvement was limited in time, that was probably due to gel formulation or lower concentration of metformin.
\end{abstract}

\section{INTRODUCTION}

Periodontal treatments such as scaling and root planing (SRP), and open flap debridement (OFD) are highly effective in halting the progression of periodontitis and maintaining disease-related defects (1). Open flap debridement is a technique which would be beneficial for reduction of periodontal pocket depth in individuals with chronic periodontitis, but don't contribute to periodontal regeneration ${ }^{(2)}$.

The healing after OFD and SRP occurs generally as long junctional epithelium that is vulnerable to the recurrence of periodontal pocket ${ }^{(3)}$. Various mediator cells, biologic and synthetic molecules and growth factor components have regenerative potential on periodontal tissues and are used in order to increase the stimulation of periodontal healing ${ }^{(4)}$.

The inflammatory response in periodontal disease includes the activation of leucocytes, neutrophils, T-lymphocytes and plasma cells 
and the release of antibodies, lipopolysaccharides and chemical inflammatory mediators that include cytokines, chemokines and C-reactive protein. The lipopolysaccharides are present in the gram-negative bacterial cell walls and act as powerful stimulants for the complex host response. The initial increased presence of neutrophils at the site is followed by the release of cytokines by neutrophils and macrophages. Chemical mediators released include tumor necrosis factor alpha (TNF $\alpha$ ), interleukin-1 (IL-1) and prostaglandins. The inflammatory process includes the stimulation of fibroblasts by IL-1 and the secretion of matrix metalloproteinases (MMPs, of which collagenase is the most prominent) by polymorph nuclear neutrophils. MMPs are responsible for increased collagen breakdown, and TNF- $\alpha$ is primarily responsible for increased osteoclast activity resulting in bone resorption. MMPs can also activate cytokines and chemokines, exacerbating the destructive process Collagen production is inhibited by the reduced activity of fibroblasts in response to TNF- $\alpha^{(5)}$.

The lymphocytes release antibodies as protective mechanisms but also activate the osteoclasts, resulting in bone loss. T-lymphocytes secrete receptor activator of nuclear factor kappa-B ligand (RANKL), which is involved in osteoclast activity and therefore bone resorption. These destructive inflammatory mediators are inhibited by the secretion of osteoprotegerin and tissue inhibitors of metalloproteinases (TIMPs) ${ }^{(6)}$.

Metformin is the most widely used first-line therapy for type- 2 diabetes. In addition to improve glucose homoeostasis, emerging evidence suggests that metformin also has dramatic protective effects on a variety of inflammatory diseases, including myocarditis, colitis, hepatitis, and arthritis ${ }^{(7)}$. In addition, recent studies reported that metformin decreased the inflammatory response, oxidative stress and bone loss in different experimental periodontitis rat models ${ }^{(8,9)}$.
The action of Metformin on the development of osteoblast-like cell lines was checked out in study that showed a direct osteogenic effect of Metformin on osteoblasts in culture ${ }^{(10)}$. The effect of the systemic administration of MF on alveolar bone resorption and the ratio of the RANKL/OPG in rats offered to experimental periapical lesions showed a decrease in the number of RANKL-positive cells and an increase in OPG-positive cells. The periapical bone loss area in the MF-treated group significantly decreased ${ }^{(11,12)}$.

Very few investigations on the effect of metformin on alveolar bone and periodontitis were preformed, only one study indicate that treatment of two wall periodontal defect with $1 \%$ Metformin was more effective in treatment of patients with chronic periodontitis ${ }^{(13)}$.

\section{PATIENTS AND METHODS}

This study was designed as randomized clinical trial, included twenty systemically healthy chronic periodontitis patients (9 males and 12 females, ranged in age from 25-30 years with mean age of $27 \pm 3.2$ years) with sever chronic periodontitis. All patients were selected from those attending at the outpatient clinic, Oral Medicine and Periodontology Department, Faculty of Dental Medicine, Al-Azhar University, Assiut branch.

A clinical examination was done to all patients participated in the study. All eligible patients were thoroughly informed of the nature, potential risks and benefits of their participation in the study and signed their informed consent documents. The study protocol was approved by the ethical committee, Faculties of Dental Medicine, Al-Azhar University.

\section{These patients were divided randomly into two groups}

Group I: ten chronic periodontitis patients with intrabony defects will receive open flap surgery alone. 
Group II: ten chronic periodontitis patients with intrabony defect will receive open flap surgery combined with $1 \%$ Metformin Gel.

\section{Presurgical preparation}

Following the initial examination, all patients received full mouth supragingival and subgingival SRP procedure under local anesthesia using ultrasonic and hand instrumentation with meticulous oral hygiene instructions. four weeks after Phase I therapy, periodontal evaluation was performed to confirm the desired sites for the study. One site with the deepest interproximal PD $\geq 5 \mathrm{~mm}$ after Phase I therapy was selected from each patient.

\section{Formulation of Metformin Gel}

Metformin (MF gel) was prepared as described by Mohapatra et al (2008) ${ }^{(14)}$. Briefly, all the required ingredients of the formulation were weighed accurately. Dry gellan gum powder was dispersed in distilled water maintained at $95^{\circ} \mathrm{C}$. The dispersion was stirred at $95^{\circ} \mathrm{C}$ for 20 minutes using a magnetic stirrer to facilitate hydration of gellan gum. The required amount of mannitol was added to the gellan gum solution with continuous stirring, and the temperature was maintained above $80^{\circ} \mathrm{C}$. A weighed amount of MF was added with stirring. Then sucralose, citric acid, and preservatives (methylparaben, propylparaben) were added with stirring. Finally, the required amount of sodium citrate was dissolved in $10 \mathrm{~mL}$ distilled water and added to the mixture. The mixture could be cooled to room temperature to form gel $1 \%$. (Fig2)

\section{Surgical Procedures}

All the surgical procedures were performed by the same person. intrasulcular incision with mucoperiosteal flap elevation, debridement of granulation tissue, subgingival SRP, and rinsing with normal saline solution were performed. Then, the patients were assigned to the groups based on the predefined random allocation. First group received debridement only. second Group underwent debridement and $1 \%$ MF was placed in the defects. (Fig 1,2)

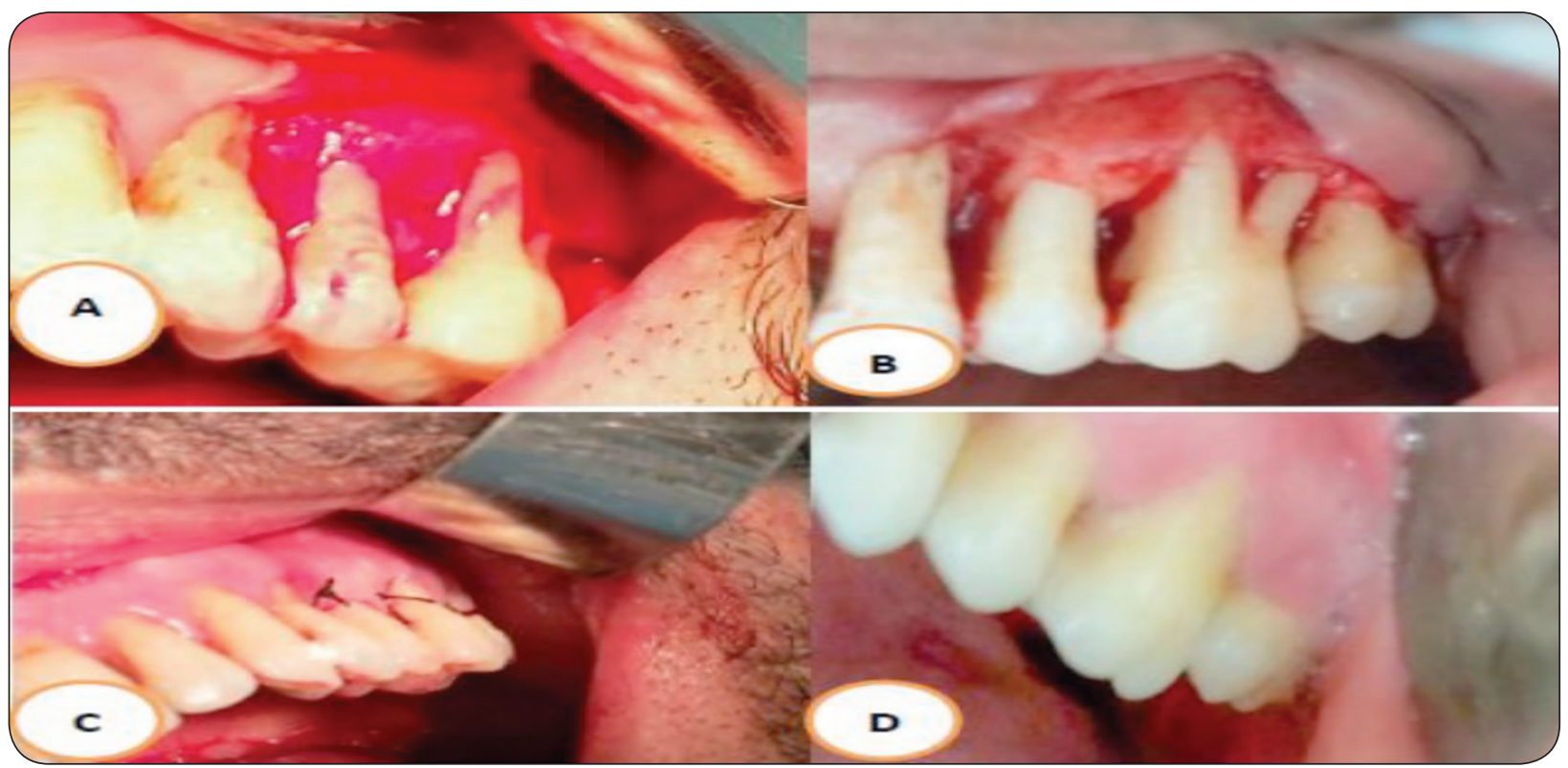

Fig. (1) Showing Clinical photographs of a patient with intrabony defect treated with open flap surgery and root debridement (A) Flap reflection. (B) Root Debridement. (C) Suturing. (D) Post-operative. 


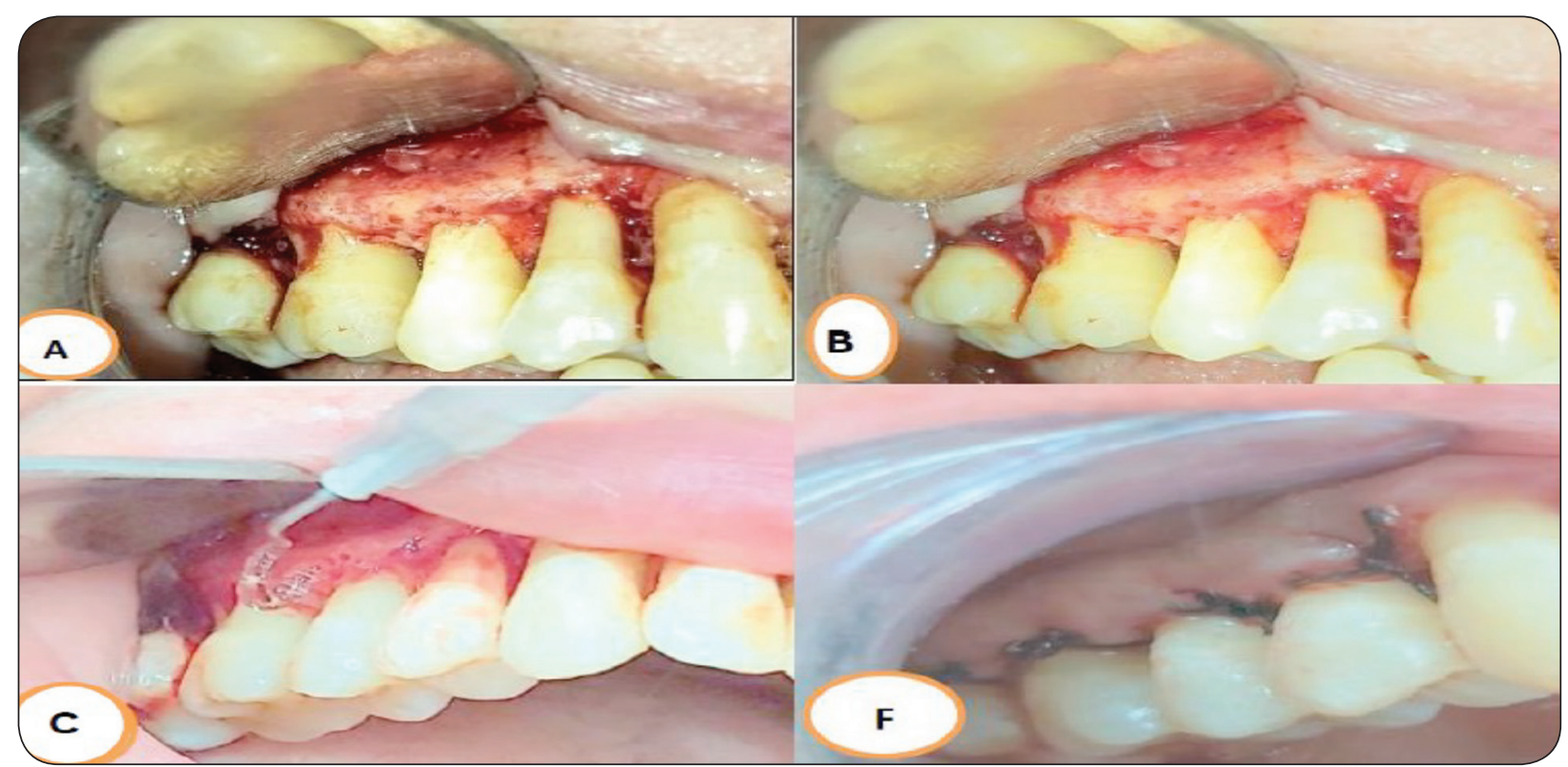

Fig. (2) Showing clinical photographs of a patient with intrabony defect treated with open flap surgery and $1 \%$ metformin gel (A) Flap reflection. (B) Root Debridement. (C) $1 \%$ Metformin gel application (D) Suturing.

\section{Clinical evaluation}

The periodontal conditions of each patient were evaluated at baseline, 6 and 9 months using the following periodontal parameters: Plaque Index (PI) ${ }^{(15)}$, Gingival Index (GI) ${ }^{(16)}$, Probing Depth (PD), Clinical Attachment Level (CAL) ${ }^{(17)}$.

\section{Radiographic evaluation}

Standardized radiographic assessment for marginal bone loss (the distance from the crest of the alveolar bone to the base of the defect) was performed at baseline, 6 and 9 months by periapical radiographs. For achieving standardization bite registration block were made for each patient to adjust film position at different intervals. Radiographs were taken by parallel technique using film holder.

\section{Statistical analysis:}

The data were collected, tabulated and statistically analyzed by Statistical Package for Social Sciences (SPSS) version 20 that programmed to produce descriptive analysis. Paired t-test used for comparison between the base line reading and the subsequent readings within the same group.
Unpaired t-test used for comparison between the groups. Graphs were performed using the Microsoft Excel 2013 program.

\section{RESULTS}

Twenty patients having chronic periodontitis with intra-bony pockets were selected to participate in this study. No abnormal reactions or complications were observed post surgically during the following 9 months observational period of the study.

In statistically checking to both plaque index and gingival index; this study recorded no statistically significant differences between both groups at any observation period checkpoint and no statistically significant differences within the groups in different observation periods. (chart no.1)

By measuring pocket depth and clinical attachment loss, there were statistically significant difference at 6 and 9 months when comparing between groups. Also, there were statistically significant differences at different periods within groups. (Table no.1, 2) 


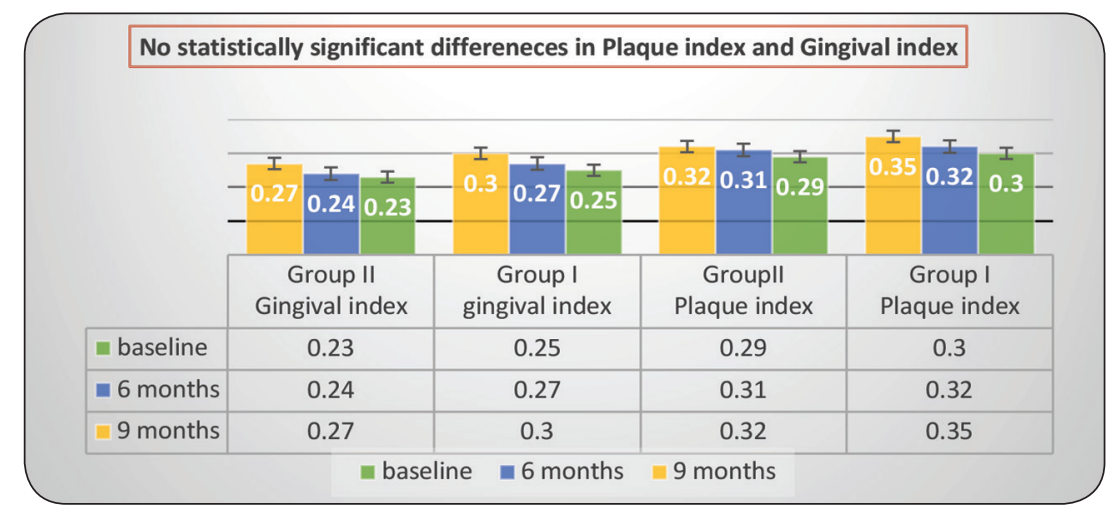

Chart (1) Showing means of plaque index and gingival index in both groups.

Table (1): Illustrating mean $\pm S D$ values of Probing Depth, clinical attachment loss and marginal bone loss scores among studied groups at each evaluation period, along with significance level using paired \& unpaired t-test.

\begin{tabular}{|c|c|c|c|c|c|c|c|c|c|c|c|c|c|c|c|c|c|c|}
\hline \multirow{2}{*}{$\begin{array}{c}\text { Clinical } \\
\text { parameters }\end{array}$} & \multicolumn{6}{|c|}{ PD } & \multicolumn{6}{|c|}{ CAL } & \multicolumn{6}{|c|}{ MBL } \\
\hline & \multicolumn{2}{|c|}{ Base line } & \multicolumn{2}{|c|}{6 months } & \multicolumn{2}{|c|}{9 months } & \multicolumn{2}{|c|}{ Base line } & \multicolumn{2}{|c|}{6 Months } & \multicolumn{2}{|c|}{9 months } & \multicolumn{2}{|c|}{ Base line } & \multicolumn{2}{|c|}{6 months } & \multicolumn{2}{|c|}{9 months } \\
\hline G1 & \multicolumn{2}{|c|}{$5.54 \pm 0.14$} & \multicolumn{2}{|c|}{$4.34 \pm 0.22$} & \multicolumn{2}{|c|}{$4.19 \pm 0.14$} & \multicolumn{2}{|c|}{$4.31 \pm 0.17$} & \multicolumn{2}{|c|}{$3.57 \pm 0.39$} & \multicolumn{2}{|c|}{$3.30 \pm 0.24$} & \multicolumn{2}{|c|}{$3.55 \pm 0.06$} & \multicolumn{2}{|c|}{$2.83 \pm 0.13$} & \multicolumn{2}{|c|}{$2.70 \pm 0.11$} \\
\hline $\mathrm{G} 2$ & \multicolumn{2}{|c|}{$5.64 \pm 0.08$} & \multicolumn{2}{|c|}{$3.85 \pm 0.33$} & \multicolumn{2}{|c|}{$3.41 \pm 0.44$} & \multicolumn{2}{|c|}{$4.2 \pm 0.10$} & \multicolumn{2}{|c|}{$3.04 \pm 0.10$} & \multicolumn{2}{|c|}{$2.7 \pm 0.15$} & \multicolumn{2}{|c|}{$3.56 \pm 0.28$} & \multicolumn{2}{|c|}{$2.38 \pm 0.3$} & \multicolumn{2}{|c|}{$2.0 \pm 0.23$} \\
\hline Unpaired $t$ test & $\mathrm{T}$ & $\mathrm{p}$ & $\mathrm{t}$ & $\mathrm{P}$ & $\mathrm{t}$ & $\mathrm{P}$ & $\mathrm{t}$ & $\mathrm{p}$ & $\mathrm{T}$ & $\mathrm{P}$ & $\mathrm{T}$ & $\mathrm{P}$ & & $\mathrm{p}$ & $\mathrm{T}$ & $\mathrm{P}$ & $\mathrm{T}$ & $\mathrm{P}$ \\
\hline G I Vs G II & 1.9 & 0.06 & 3.9 & $0.00 *$ & 5.34 & 0.00 * & 1.7 & 0.09 & 4.1 & $0.00^{*}$ & 6. & 0.00 & & 0.91 & 4.35 & $0.00^{*}$ & 8.6 & $0.00 *$ \\
\hline
\end{tabular}

Table (2): Illustrating significance of Probing Depth, clinical attachment loss and marginal bone loss scores among studied groups using paired \& unpaired t-test.

\begin{tabular}{|c|c|c|c|c|c|c|c|c|c|c|c|c|c|c|c|c|c|c|}
\hline \multirow{3}{*}{$\begin{array}{c}\text { Clinical } \\
\text { parameters }\end{array}$} & \multicolumn{6}{|c|}{ PD } & \multicolumn{6}{|c|}{ CAL } & \multicolumn{6}{|c|}{ MBL } \\
\hline & \multicolumn{2}{|c|}{$\mathrm{t}$} & \multicolumn{2}{|c|}{$\mathrm{P}$} & \multicolumn{2}{|c|}{$\mathrm{t}$} & \multicolumn{2}{|c|}{$t$} & \multicolumn{2}{|c|}{$\mathrm{P}$} & \multicolumn{2}{|c|}{$\mathrm{t}$} & \multicolumn{2}{|c|}{$\mathrm{t}$} & \multicolumn{2}{|c|}{$\mathrm{P}$} & \multicolumn{2}{|c|}{$\mathrm{t}$} \\
\hline & \multicolumn{2}{|c|}{$\begin{array}{l}6 \text { Months } \\
\text { vs } \\
\text { baseline }\end{array}$} & \multicolumn{2}{|c|}{$\begin{array}{c}9 \text { Months } \\
\text { vs } \\
\text { baseline }\end{array}$} & \multicolumn{2}{|c|}{$\begin{array}{l}6 \text { Months } \\
\text { vs } \\
\text { 9Months }\end{array}$} & \multicolumn{2}{|c|}{$\begin{array}{l}6 \text { Months } \\
\text { vs } \\
\text { baseline }\end{array}$} & \multicolumn{2}{|c|}{$\begin{array}{l}9 \text { Months } \\
\text { vs } \\
\text { baseline }\end{array}$} & \multicolumn{2}{|c|}{$\begin{array}{l}6 \text { Months } \\
\text { vs } \\
\text { 9Months }\end{array}$} & \multicolumn{2}{|c|}{$\begin{array}{l}6 \text { Months } \\
\text { vs } \\
\text { baseline }\end{array}$} & \multicolumn{2}{|c|}{$\begin{array}{l}9 \text { Months } \\
\text { vs } \\
\text { baseline }\end{array}$} & \multicolumn{2}{|c|}{$\begin{array}{l}6 \text { Months } \\
\text { vs } \\
\text { 9Months }\end{array}$} \\
\hline G1 & 11.4 & $0.00 *$ & 16.5 & $0.00^{*}$ & 2.6 & $0.02 *$ & 4.8 & $0.00^{*}$ & 8.9 & $0.00 *$ & 3.1 & $0.01 *$ & 16.4 & $0.00 *$ & 21.8 & $0.00 *$ & 5.7 & $0.00 *$ \\
\hline G2 & 14.2 & $0.00 *$ & 14.5 & $0.00^{*}$ & 2.8 & $0.01 *$ & 28.8 & $0.00^{*}$ & 22.3 & $0.00^{*}$ & 7.5 & $0.00 *$ & 9.4 & $0.00 *$ & 13.6 & $0.00 *$ & 5.5 & $0.00 *$ \\
\hline
\end{tabular}

By investigating marginal bone loss, this study showed that there was statistically significant difference at 6 and 9 months when comparing between groups. Also, there were statistically significant differences at different periods within group. (Table no1, 2)

\section{DISCUSSION}

The goal of periodontal therapy is to save existing teeth or replace missing one. Angular intrabony defects are signs of periodontal disease progression which leading to losing the tooth. The successful management of periodontal pockets associated with infrabony defects through nonsurgical treatment alone is an unpredictable treatment modality. 
Optimum outcome of such management would be complete pocket resolution and ideally with new attachment formation. In order to achieve this predictably, several regenerative surgical techniques have been developed, alongside the use of a multitude of osteoconductive or osteoinductive regenerative materials ${ }^{(18)}$.

Metformin was selected in this study because it characterized by increased expression of osteogenic genes leading to osteoblast differentiation, which could generate additional benefits in bone repair and periodontal healing, and have a beneficial effect when associated with periodontal therapy since it would increase osteoblastic differentiation, thus MF improving results of conventional periodontal treatment. Metformin gel $1 \%$ was used in the present study because it gives a better drug release pattern and better clinical efficacy as compared to $0.5 \%$ and $1.5 \%$ metformin MF gels in treatment of chronic periodontitis patients ${ }^{(19)}$.

The clinical parameters were used in this study included: plaque index, gingival index probing depth, and clinical attachment level; plaque index and gingival index were recorded to assess the oral hygiene maintenance and inflammatory status at various time intervals, probing depth and clinical attachment level were assessed to evaluate the outcome of various treatment modalities ${ }^{(20)}$. Plaque is considered an important factor in the initiation, progression, and severity of periodontal infection and a major contributor to failure of periodontal treatment procedures thus, the current study included only those participants who were able to maintain acceptable oral hygiene after phase I therapy ${ }^{(21)}$.

The evaluation of hard tissue changes after regeneration therapy can be done either by surgical re-entry procedure or by radiographic assessment. However, re-entry procedures require a second surgical intervention which is usually not acceptable to the patient. Furthermore, it may cause a disturbance of the new connective tissue attachment. Radiographic assessment, however, provides a non-invasive method for evaluating the hard tissue changes.

In the current study, digital radiography was taken for all patients before \& during observation periods because digital views could support the image storage, printing and allow handling by different software and to avoid variations in the contrast and density caused by poor control of film processing, routine standardized periapical views with presurgical recorded bite registration impressions and long cone paralleling technique using film holder this produces images of the teeth on the receptor with minimal distortion ${ }^{(22)}$.

The present investigation showed that gingival index with no statistically significant differences between both groups at any observation periods. This result similar to other finding; (13) they concluded that treatment of two-walls intra-bony defect with Metformin did not significantly improve clinical parameters (gingival index) in comparison with the control group. however, data improved significantly in each group from the beginning to the end of the study.

The present study found that, pocket depth (PD) and clinical attachment loss values reduction values were higher in MF+OFD than OFD alone this agrees with the study of Pradeep et al (2016) ${ }^{(11)}$ they stated that a significant reduction in PD and gain in CAL was found in all groups at 9 months postoperatively. $\mathrm{PD}$ reduction and CAL gain were also greater in the $1 \% \mathrm{MF}$ group sites compared to control sites, the difference being statistically significant.

The present trial recorded that; after periodontal surgery the scores of marginal bone loss decreased in all groups at 9 months postoperatively and this reduction was statistically significant in the $1 \%$ MF group sites compared to control sites. This in accordance with other study ${ }^{(11)}$ they mentioned that The MBL reduction in MF group was significantly greater than in the OFD-only group, showing the benefit of the use of metformin in periodontal regeneration. 


\section{CONCLUSIONS}

Within the limitations of this trial, there was significant PD reduction, CAL gain, and greater radiographic defect depth reduction in the $1 \% \mathrm{MF}$ + OFD group compared to OFD group. These result indicated that a possible role of metformin in periodontal therapy.

\section{REFERENCES}

1. Deas E, Moritz J, Sagun S, Jr., Gruwell F, Powell A. Scaling and root planing vs. conservative surgery in the treatment of chronic periodontitis. Periodontol 2000. 2016;71(1):128-39.

2. Joseph R, Sam G, Amol V. Clinical evaluation of autologous platelet rich fibrin in horizontal alveolar bony defects. J Clin Diagn Res. 2014;8(11): Zc43-7.

3. Hägi T, Laugisch O, Ivanovic A, Sculean A. Regenerative periodontal therapy. Quintessence Int. 2014;45(3):185-92.

4. Gamal Y, Abdel Ghaffar A, Alghezwy A. Crevicular Fluid Growth Factors Release Profile Following the Use of Platelet-Rich Fibrin and Plasma Rich Growth Factors in Treating Periodontal Intrabony Defects: A Randomized Clinical Trial. J Periodontol. 2016;87(6):654-62.

5. Di Paola R, Briguglio F, Paterniti I, Mazzon E, Oteri G, Militi D, et al. Emerging role of PPAR $-\beta / \delta$ in inflammatory process associated to experimental periodontitis. Mediators Inflamm. 2011;2011:787159.

6. Hienz A, Paliwal S, Ivanovski S. Mechanisms of Bone Resorption in Periodontitis. J. Immunol. Res. 2015;2015:6154-86.

7. Tan Y, Chen J, Jiang Y, Chen X, Li J, Chen B, Gao J. The Anti-Periodontitis Action of Metformin via Targeting NLRP3 Inflammasome. Arch Oral Biol. 2020; 4: e104692.

8. Araujo A, Pereira A, Medeiros C, Brito G, Leitao R, Araujo L. et al. Effects of metformin on inflammation, oxidative stress, and bone loss in a rat model of periodontitis. PLoS One. 2017; 12(8): e 0183506.

9. Khajuria D, Patil O, Karasik D, Razdan R. Development and evaluation of novel biodegradable chitosan-based metformin intrapocket dental film for the management of periodontitis and alveolar bone loss in a rat model. Arch Oral Biol. 2018; 85:120-9.
10. Cortizo A, Sedlinsky C, McCarthy A, Blanco A, Schurman L. Osteogenic actions of the anti-diabetic drug metformin on osteoblasts in culture. European journal of pharmacology. 2006;536(1-2):38-46.

11. Pradeep A, Patnaik K, Nagpal K, Karvekar S, Ramamurthy B, Naik S, et al. Efficacy of locally delivered $1 \%$ metformin gel in the treatment of intrabony defects in patients with chronic periodontitis: a randomized, controlled clinical trial. J Investig Clin Dent. 2016;7(3):239-45.

12. Rao N, Pradeep A, Kumari M, Naik S. Locally delivered $1 \%$ metformin gel in the treatment of smokers with chronic periodontitis: a randomized controlled clinical trial. J periodontol. 2013;84(8):1165-71.

13. Khalifehzadeh S, Haghanifar S, Jenabian N, Kazemi S, Hajiahmadi M. Clinical and radiographic evaluation of applying $1 \%$ metformin biofilm with plasma rich in growth factor (PRGF) for treatment of two-wall intrabony periodontal defects: A randomized clinical trial. J Dent Res Dent Clin Dent Prospects. 2019;13(1):51-6.

14. Mohapatra M, Parikh R, Gohel M. Formulation, development and evaluation of patient friendly dosage forms of metformin, part-II: Oral soft gel formulation, development and evaluation of patient friendly dosage forms of metformin. J Pharm. 2008; 2:172-6.

15. Sliness J., Loe H. Periodontal disease in pregnancy (II). Correlation between oral hygiene and periodontal conditions. Acta Odont Scan. 1964; 24: 747 - 59.

16. Loe H., Sliness J. Periodontal disease in pregnancy (I) prevalence and severity. Acta Odont Scan 1963; 21: 533- 51.

17. Ramfjord S.P. The periodontal disease index (PDI). J Periodontal (1967); 38: 602 -610.

18. Al-Falaki R, Hughes FJ, Wadia R. Minimally invasive treatment of infrabony periodontal defects using dualwavelength laser therapy. International scholarly research notices. 2016; 2016; 71759-19.

19. Pradeep R, Rao S, Naik B, Kumari M. Efficacy of varying concentrations of subgingivally delivered metformin in the treatment of chronic periodontitis: a randomized controlled clinical trial. J Periodontol. 2013;84(2):212-20.

20. Loe H. The Gingival Index, the Plaque Index and the Retention Index Systems. J Periodontol. 1967;38(6):610-6.

21. Trombelli L, Kim C, Zimmerman G, Wikesjo“ U. Retrospective analysis of factors related to clinical outcome of guided tissue regeneration procedures in intrabony defects. J Clin Periodontol.1997;24:366-71.

22. Golubow A, Farman G, von Fraunhofer A, Kelly S. Direct digital radiography for the detection of defects in a standard aluminium test object through composite resin restorative materials. Dento maxillofac Radiol. 1994;23(2):91-6. 


\section{تأثير الميتفورمين في العلاج الجراحي للخلل العظمي حول السني}

\section{(دراسة مقارنة إكلينيكة و بالأشعة )}

حسام جمال *, عاصم محمد كامل , فتحى عبدالعظيم أبو زيد

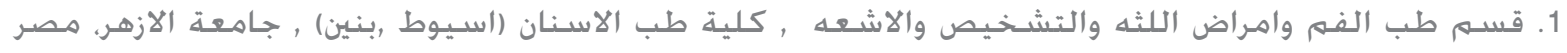
* البريد الإلكتروني للباحث الرئيسي: HOSSAMABDELWAHAB.2046@AZHAR.EDU.EG *

(الملخص:

الهدف: أجريت هذه الدراسـه للتقيبه الإكلينيكى وبالأشعه لفاعلية تأثير استخدام المبتفورمين في العلاج الجراحي للخلل العظمي حول

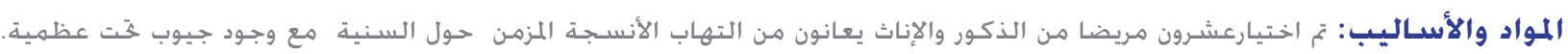

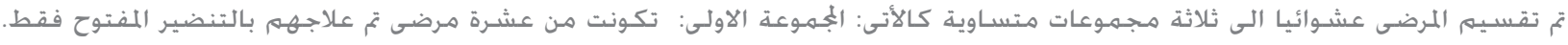

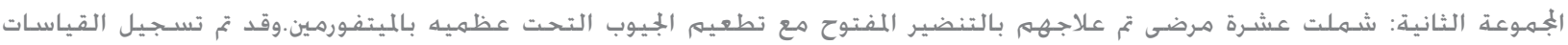

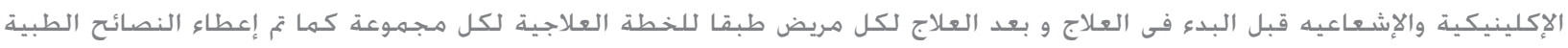

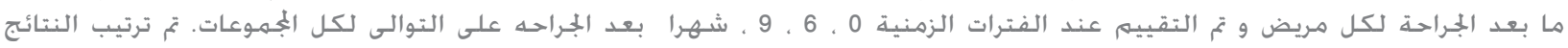
وجدولتها و تقييمها إحصائيا.

النتائج: أظهرت النتائج وجود فروقات إحصائية بين البُموعتين الاولى و الثانية في دليل قياس الجيوب اللثوية و دليل مستوي إلتصاق اللثه الرأسي و دليل مستوى حافة العظم بعد 6 أشهر من بداية العلاج الجراحى، عدم وجود فروقات إحصائية بلئية بين الجمهوعتين الأولى والثانيه بعد 9 أشهر من بداية العلاج.

الخلاصه : أستخدام الميتفورمين مع التنضير المفتوح أظهر فاعلية فى علاج الخنل التحت عظمي اكثر من أستخدام التنضير المفتوح فقط. الكلمات المفتاحبه: ميتفورمين , التهاب الأنسجة حول السنية , ججدد المخلايا , جيوب ثخت عظمية, الجيوب اللثوية. 